\title{
Internal Migrations as a Driving Force of Regional Disintegration: An Empirical Analysis of NUTS-2 Regions in Turkey
}

\author{
Ayfer Özyllmaz \\ Yüksel Bayraktar
}

\begin{abstract}
Internal migrations, which involve population movements within the borders of a country for economic, political or social reasons, is seen as both a cause and a result of regional imbalances. In this framework, the effect increasing internal migrations have on developed and underdeveloped regions may differ through the effect of the different socio-cultural and economic conditions between regions. The aspect of imbalance is directly related to the extent to which migration affects parameters such as wage, production, consumption, human capital levels, entrepreneurial migration, unemployment, and household income in regions with different stages of development. This study analyzes the effect internal migration has on regional imbalances in Turkey's NUTS-2 regions during 2008-2019 using the bootstrap quantile regression method. According to the analysis findings, internal migration increases growth in all NUTS-2 regions, but this effect is stronger at higher income levels. In this context, as a region's income levels increase, the effect of net migration on growth also increases. When considering the migration direction to be from low-income regions to high-income regions, internal migration has been found to increase interregional disintegration in Turkey.
\end{abstract}

Keywords: Internal migration, regional disintegration, regional disparities, regional imbalance, bootstrap quantile regression.

Öz: Ekonomik, politik veya sosyal nedenlerle ülke sınırları içindeki nüfus hareketlerini kapsayan iç göçler bölgesel dengesizliklerin hem sebebi hem de sonucu olarak ön plana çıkmaktadırlar. Bu çerçevede bölgeler arasındaki sosyo-kültürel ve iktisadi koşulların etkisi ile artan iç göçlerin gelişmiş ve azgelişmiş bölgeler üzerindeki etkisi farklılaşabilmektedir. Dengesizliğin yönü ise göçlerin farklı gelişmişlik düzeyine sahip bölgelerin ücret, üretim, tüketim, beşeri sermaye düzeyi, girişimci göçü, işsizlik, hane halkı geliri gibi parametleri ne oranda etkilediği ile doğrudan ilişkilidir. Bu çalışmada, Türkiye'de Düzey-2 bölgelerinde 2008-2019 döneminde iç göçlerin bölgesel dengesizlikler üzerindeki etkisi Bootstrap Kantil Regresyon yöntemi kullanılarak analiz edilmiştir. Analiz bulgularına göre iç göçler, tüm Düzey-2 bölgelerinde büyümeyi artırmakta ancak bu etki yüksek gelir düzeylerinde daha güçlüdür. Bu bağlamda, bölgelerin gelir düzeyleri arttıkça net göçün büyüme üzerindeki etkisi de artmaktadır. Göç yönünün düşük gelirli bölgelerden yüksek gelirli bölgelere doğru olduğu göz önüne alındığında, Türkiye’de iç göçlerin bölgeler arasındaki ayrışmayı artırdığı bulgusuna ulaşılmıştır.

Anahtar Kelimeler: İç göç, bölgesel ayrışma, bölgesel farklılıklar, bölgesel dengesizlik, bootstrap kantil regresyon.

* This study was based on the doctoral dissertation "The Effect of Internal Migration on Regional Imbalance: The Case of Turkey".

(a)

Assist. Prof., Kocaeli Üniversitesi. ozyilmazayfer@gmail.com

Prof. Dr. İstanbul Üniversitesi. ybayraktar@istanbul.edu.tr

(iD)

https://orcid.org/0000-0001-9201-2508

https://orcid.org/0000-0002-3499-4571

(C) İlmi Etüdler Derneği

DOI: 10.12658/M0632

insan \& toplum, 2021. 


\section{Introduction}

The first studies on migration started with Ravenstein's Laws of Migration (1885, 1889); afterwards, many approaches have been published to explain migration. In this context, Stouffer (1940) emphasized the migration-distance relationship; Lee (1966) argued push and pull factors; and Lewis (1954), Todaro (1969) and HarrisTodaro (1970) argued migrations to be based on wage differences between countries based on Hicks' (1932) neo-classical macro theory. Schultz (1971) and Todaro (1980) emphasized the importance of benefits and costs in migration decisions based on Sjaastad's (1962) cost-benefit approach. Piore (1979) referred to labor force demand being caused by industrialization in his dual labor market thesis. Meanwhile, Wallerstein (1974) based migration on the differences in labor and capital between core and periphery countries in the world-systems theory. Massey et al. (1987), Boyd (1989), and Fawcett (1989) emphasized relations networks and suggested that networks between migrants and potential migrants are decisive for migration. Stark $(1978 ; 1991)$ provided a new perspective on migration with his theory of the new economics of migration, which bases migration on minimizing the risks of things such as drought, hurricane, or sudden unemployment. Each of these theories provide a significant contribution to the migration literature from different perspectives.

Most of migrations are based on economic reasons such as unemployment and better living conditions (Thet, 2014; Piesse, 2014); however, in agriculture-dominated economies in particular, low agricultural productivity is one of the major causes of migration (Deshingkar \& Grim, 2004). In addition, prominent factors in migration decisions are globalization (Čiarnienè \& Kumpikaité, 2008); education (Rosenzweig, 2005); natural disasters such as earthquakes, hurricanes, and floods (Hear, Bakewell, \& Long, 2012), migration legislation (Deshingkar \& Grimm, 2004); war and invasion (Rose et al., 2011); political instability (Williams \& Pradhan, 2009); socio-cultural opportunities (Cultland, 2011); and climatic conditions (Broeck \& Lilleør, 2011).

Migrations affects labor markets (Organisation for Economic Co-operation and Development [OECD], 2016), economic growth (Bayraktar \& Özyllmaz, 2019; Gómez \& Giráldez, 2017), poverty (Bayraktar \& Özyılmaz, 2018; Skeldon, 1997), education (Amuedo-Dorantes \& Pozo, 2010), production and consumption (Adams \& Cuecuecha, 2013), and social structure (Öztürk \& Altuntepe, 2008) in various ways. Migrations affect social life by way of things such as slums and urban harmony problems (Es \& Ateş, 2004) and outbreaks (Bayraktar et al., 2020) and is also directly related to crime rates. In addition, remittances provide additional income for education, housing, and 
health expenditures (Adams \& Cuecuecha, 2013), as well as insurance against cyclical shocks, especially in lower-income households (Airola, 2007). Meanwhile, migration plays a decisive role in regional disparities in various ways. For example, increases in wage inequalities (Ackah \& Medvedev, 2012; Wolszczak-Derlacz, 2009) and production capacity (Kangasniemi et al., 2012) lead to loss of productive labor (Haque \& Kim, 1995; Wang, 2014) and provide additional household income through remittances (Özyllmaz et al., 2019; Wondimagegnhu, 2012).

One of the topics of discussion in the literature is the impact internal migration has on regional imbalance. While internal migration may lead to an increase in production due to the increase in labor demand through industrialization in developed regions and thus an increase in economic growth, it may also cause a loss of human capital and a decrease in agricultural production, slowing the development rate of rural areas (Bayraktar \& Özyılmaz, 2019). Therefore, internal migration can have a positive effect on output in both developed and underdeveloped regions. However, the opposite may also be the case. Therefore, the net effect of internal migration varies by country and by region.

Turkey is one of the countries with high regional disparities. Economic and socio-cultural opportunities as well as direct foreign investments are clustered in the relatively developed regions of East Marmara, West Marmara, Istanbul, Western Anatolia, and Mediterranean regions; Eastern Turkey, in particular Central Anatolia and the Black Sea regions, are underdeveloped socio-economically. Employment, security, education, and low agricultural productivity are among the causes of internal migration as well as interregional development differences. Table 1 includes some macroeconomic indicators in order to reveal the interregional differences. 


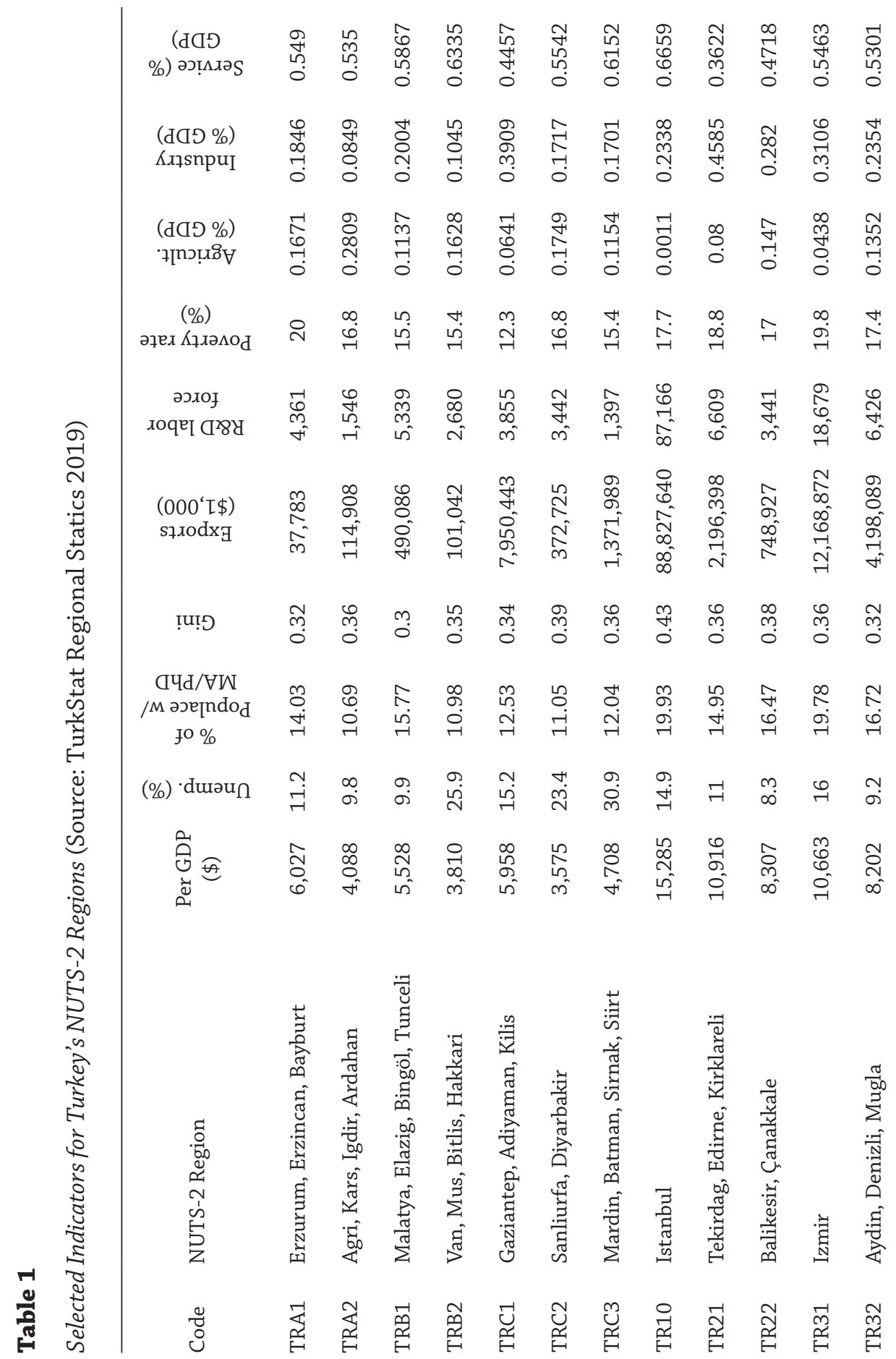




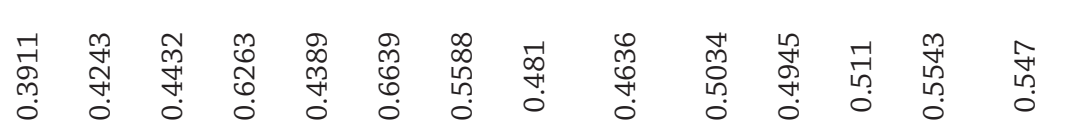

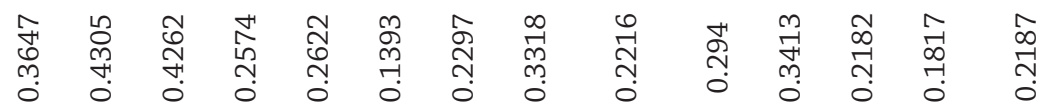

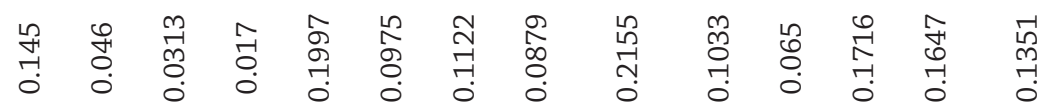

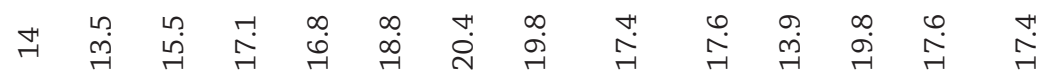

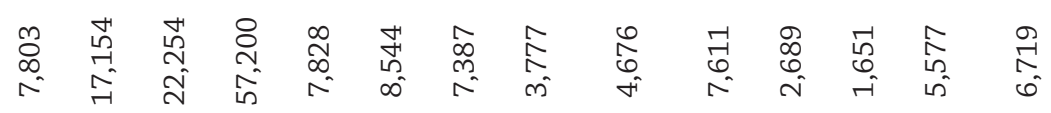

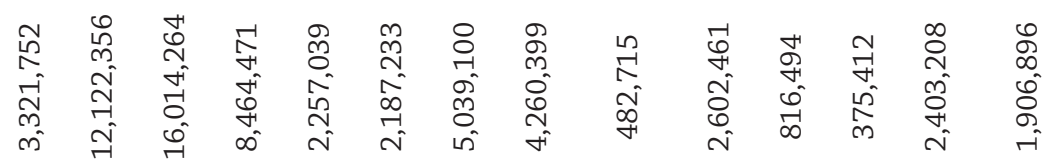

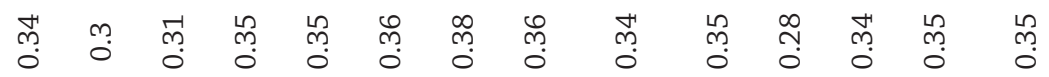

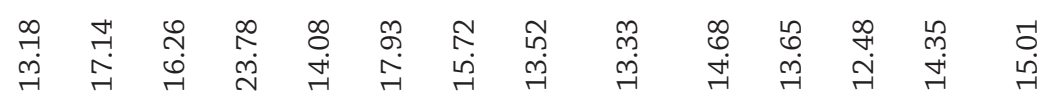

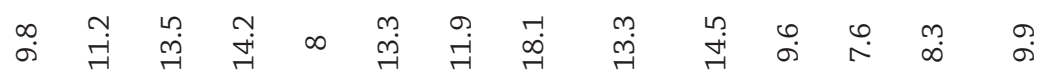

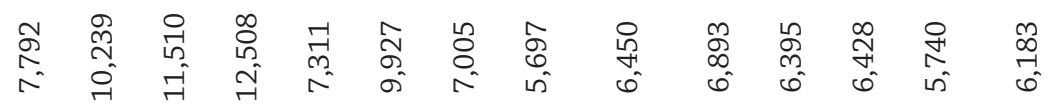

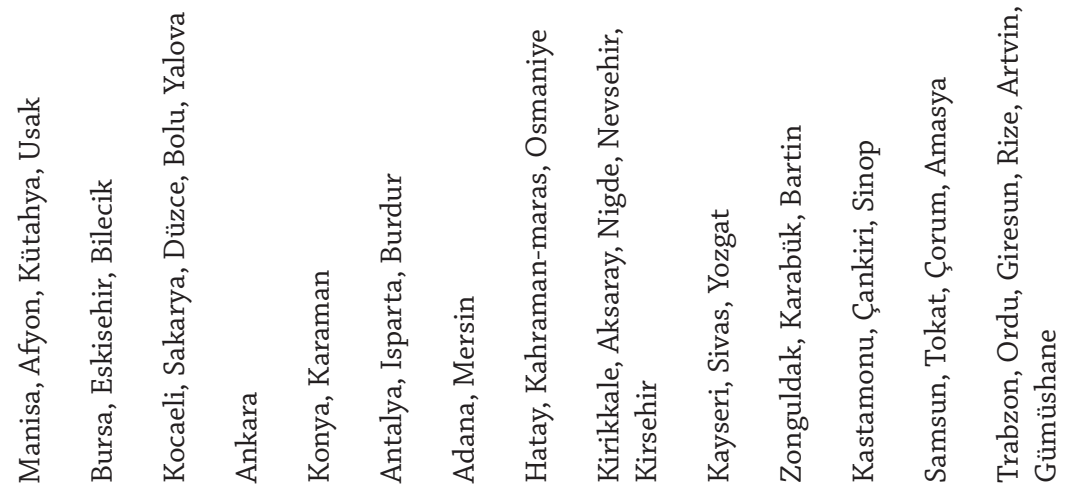

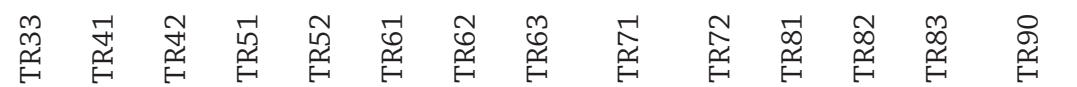


When analyzing the data in Table 1 , high differences are found among regional indicators such as income, education, export, R\&D workforce, and unemployment. The difference between low- and high-income regions in per capita income is as high as $400 \%$. For example, while the per capita income is $\$ 15,285$ in TR10 (Istanbul, Tekirdağ), it is $\$ 3,575$ in TRC2 (Sanliurfa, Diyarbakir). A similar trend exists in unemployment rates. Unemployment reaches $30 \%$ in some low-income regions, with this rate being relatively lower in high-income regions. Meanwhile, interregional export differences are also very high. Education levels also increase with income level, but the regional differences in this variable are relatively low. A similar trend is also observed for poverty rates, while this trend is reversed for income inequality. Inequality appears to be higher in high-income regions. When examining regions' sectoral structures, the share of agriculture in GDP, which is very low in high-income regions, is seen to be higher in low-income regions. In this framework, the role regions' sectoral structures have in interregional imbalances can be seen more clearly.

The first part of the study has presented the causes and consequences of migrations. The second part will present the literature. The third section will detail the data and method and the fourth section will discuss the empirical findings.

\section{Literature}

The literature contains many studies on the relationship between migration and regional disparities, with the transmission mechanism varying with respect to country. While some studies emphasize remittances, some of them emphasize the importance of labor and productivity. Therefore, while migration increases regional disparities in some countries, in others it decreases regional disparities.

According to the studies emphasizing migration to increase regional disparities, the determining factors are as follows: human capital migration; the involvement of capital and entrepreneurs in the migration process in addition to the labor force; only high-income and middle-income households being able to migrate due to high costs and low remittances; and return migrations being comprised of the elderly, the sick, or those in need of care. All of these have a negative impact on the development of the out-migration regions and a positive effect on the in-migration regions, thus deepening regional disparities.

One of migration's effects on rural economies is closely related to the acceleration of agricultural production. In terms of the agricultural sector, temporary agricultural workers, who are an important workforce at harvest time, as well as the rural 
workforce are critically important for attaining the required workforce. Therefore, the heavy flow of out-migration from agriculturally based economic regions may adversely affects these regions' economic growth (Bayraktar \& Özyılmaz, 2019; Gurgand et al., 2014).

The most prominent arguments in studies suggesting that migration will reduce regional inequalities are remittances and migration's effect on wages. With the migration of labor from low-income regions to high-income regions, wages are expected to decline with the increasing labor supply in high-income regions, while wages are expected to rise with the decreased labor supply in the low-income regions. Therefore, regional differences are expected to decrease as wages converge. A similar effect exists for remittances. Remittances, which are an important source of income in rural areas in particular, are expected to reduce regional imbalances.

Migration's contributions to innovation are also determinant in creating regional differences. In this context, migrations not only increase the population of the region but also sometimes have a positive effect on innovation. This situation directly affects the growth potential of regions and is one of the factors recently emphasized in the relationship migration has with interregional imbalance (Zhao \& Li, 2020; Freeman, 1997). Migrants consisting primarily of a qualified workforce is found to directly increase innovation (Mare et al., 2011).

Borozan (2017) suggested net migration to increase regional disparities and brain drain to have played an important role in these results in Croatia. Wang (2014) found regional disparities to increase due to the poor's inability to migrate as a result of high migration costs in China. Ackah and Medvedev (2012) argued internal migration to lead to interregional productivity differences by disrupting qualified labor distribution in Ghana; Coulombe and Tremblay (2009) argued the same to happen in Canada, as did Fratesi and Riggi (2007) in developed countries and Lipton (1980) in India. Meanwhile, increasing production and consumption positively affects regional development in the regions receiving migration, and this deepens regional disparities.

Phan and Coxhead (2010) found the effect of interprovincial migration on the regional disparities to depend on the region being migrated to, with migration toward industry-intensive regions having reduced regional disparities in Vietnam. According to Zhu and Luo (2010), the expanding labor market brings sectoral developments in urban areas through migration in China; they found this to lead to an expansion of rural production, to increase employment, and to reduce regional disparities. Zhai et al. 
(2003) argued labor force to decrease in agricultural areas and food prices to increase through the migration of semi-skilled and unskilled labor from rural to urban areas in China; this had positively affected rural regions and reduced rural-urban disparities. According to Guest (1998), remittances in Thailand had increased household income in rural areas; increasing income had created a multiplier effect on the economy by expanding expenditures, thus resulting in regional disparities tending to decrease.

Despite articles suggesting migration to be a determinant of regional disparities, Vakulenko (2016) in Russia and Nguyen et al. (2013) in Vietnam both concluded migrations to not be effective in reducing regional disparities. According to Zhang (2015), the impact of internal migration on regional disparities in China differs with respect to region and time. In this context, while migration increases regional disparities in some countries, it causes regional disparities to decrease in others.

Some studies in the literature have discussed the relationship between internal migration and regional disparities within the framework of convergence analysis, which is the hypothesis of neoclassical theory. According to the theory, per capita income decreases in the in-migration regions and increases in the out-migration regions as a result of labor-force migrations from low-income to high-income regions. Thus, regional income disparities disappear over time; at the end of the process, migrations begin to slow down. When the effects of internal migration on regional disparities are examined within the framework of the convergence hypothesis, Barro and Sala-i-Martin (2004) in the USA and Japan, Østbye and Westerlund (2007) in Sweden, Haaf and Kool (2017) in Germany, and Maza (2006) in Spain all found internal migration to accelerate regional convergence.

Kirdar and Saracoglu (2012) in Turkey, Bunea (2011) in Romania, and Persson (1997) in Sweden all found no evidence for internal migration contributing to regional convergence. While Fratesi and Percoco (2014) emphasized internal migration in Italy to have had a negative impact on convergence, Gezici and Hewings (2004) found this effect to be negative and insignificant in Turkey.

\section{Data and Methods}

This study analyzes the impact of internal migration on regional disparities in Turkey's NUTS-2 regions over the 2008-2019 period. The analysis uses the real per GDP $\left(L G D P_{\mathrm{it}}\right)$ as the dependent variable and includes net internal migration $\left(M I G_{\mathrm{it}}\right)$, employment rate $\left(E M P_{\mathrm{it}}\right)$, inflation $\left(I N F_{\mathrm{it}}\right)$, and education level $\left(E D U_{\mathrm{it}}\right)$ as the independent variables. The equation for the model is: 


$$
\mathrm{LGDP}_{\mathrm{it}}=\alpha_{\mathrm{i}}+\beta_{1} \mathrm{MIG}_{\mathrm{it}}+\beta_{2} \mathrm{EMP}_{\mathrm{it}}+\beta_{3} \mathrm{INF}_{\mathrm{it}}+\beta_{4} \mathrm{EDU}_{\mathrm{it}}+\mathrm{u}_{\mathrm{it}}
$$

The data used in the study were obtained from the Turkish Statistical Institute (TurkStat) and explanations for all variables are presented in Table 2.

\section{Table 2}

Data Description

\begin{tabular}{cc}
\hline Variables & Description \\
$L G D P$ & GDP per capita (TL, based on 2009) \\
$M I G$ & Net Migration \\
$E M P$ & Employment Rate (\%) \\
$I N F$ & Consumer price index (\%) \\
EDU & Percentage of Populace with MA/PhD (\%) \\
\hline
\end{tabular}

The study uses panel bootstrap quantile regression estimators. Quantiles are resistant to extremes in the dependent variable. Quantile regression analysis also provides more effective results than least squares estimators when the data is not normally distributed. Quantile regressions are widely used in areas where data have distorted distributions such as income and wages variations and is a method designed to present more comprehensive regression findings (Güriş \& Sak, 2019; Erilli \& Çamurlu, 2018; Koenker, 2005; Leping 2005).

The quantile regression method was developed by Koenker and Bassett (1978). Quantile regression provides robust estimation results in the presence of outliers, allowing parameter estimations in different quantile values from the conditional distribution of the dependent variable. For $\theta$ quantile regression, the minimization equation is as follows:

$$
\min \left(\beta \in R^{K}\right)\left[\sum\left(i \in\left\{i: y_{i} \geq x_{i}^{\prime} \beta\right\}\right) \theta\left|y_{i}-x_{i}^{\prime} \beta\right|+\sum\left(i \in\left\{i: y_{i}<x_{i}^{\prime} \beta\right\}\right)(1-\theta)\left|y_{i}-x_{i}^{\prime} \beta\right|\right]
$$

Equation 2 takes a value between 0 and 1 and shows the level of the quantile. For the dimension $K x, \mathrm{x}_{\mathrm{i}}$ is the vector of the explanatory variables. When generalizing Equation (2) to the model, the following equation for the linear regression model results:

$$
\mathrm{y}_{\mathrm{i}}=\mathrm{x}_{\mathrm{i}}^{\prime} \beta_{\theta}+\mathrm{u}_{\theta \mathrm{i}}, \quad \operatorname{Kant}_{\theta}\left(\mathrm{y}_{\mathrm{i}} / \mathrm{x}_{\mathrm{i}}\right)=\mathrm{x}_{\mathrm{i}}^{\prime} \beta_{\theta}
$$

$\operatorname{Kant}_{\theta}\left(\mathrm{y}_{\mathrm{i}} / \mathrm{x}_{\mathrm{i}}\right)$ indicates the conditional quantile of $\mathrm{y}_{\mathrm{i}}$ conditional to the independent variable vector $\mathrm{x}_{\mathrm{i}}$ (Saçıldı \& Koşan, 2015; Buchinsky, 1998; Koenker \& Bassett 1978). However, the bootstrap method is prefered due to the small sample size, as this method is particularly superior over small data sets (Özel \& Sezgin, 2012). 


\section{Empirical Results}

In cases where data are not normally distributed, quantile regression analysis can give more effective results. The study uses descriptive statistics to determine the distribution properties of the series (Güriş \& Sak, 2019); the descriptive statistics for the variables used in the study are presented in Table 3 .

\section{Table 3}

Descriptive Statistics

\begin{tabular}{ccccccccc}
\hline Variables & Mean & Median & Max. & Min. & \multicolumn{2}{c}{ Std. Err. Skewness } & Kurtosis & Jarque-Bera (Prob) \\
LGDP & 9.876 & 9.863 & 11.371 & 8.546 & 0.570 & 0.027 & 2.562 & $2.5310(0.2820)$ \\
MIG & -1.504 & 2.075 & 60.260 & -35.150 & 9.723 & 0.436 & 8.184 & $359.3695^{*}(0.0000)$ \\
EMP & 44.973 & 46.150 & 57.600 & 25.400 & 6.154 & -0.978 & 3.950 & $61.5314^{*}(0.0000)$ \\
INF & 98.319 & 8.705 & 18.260 & 4.180 & 3.315 & 1.109 & 3.107 & $64.1142^{*}(0.0000)$ \\
EDU & 11.003 & 10.820 & 23.780 & 2.960 & 3.931 & 0.421 & 3.133 & $9.4574^{*}(0.0088)$ \\
\hline
\end{tabular}

* indicates rejection of the null hypothesis (normal distribution at a $5 \%$ level of significance).

Meanwhile, when examining the descriptive statistics of the series in Table 2, all variables except for $L G D P$ are observed to lack normal distribution at a $1 \%$ level of significance and to contain extreme values. Therefore, the study has preferred the quantile regression method as it is less sensitive to extreme values. The bootstrap quantile regression method is used with 10,000 replications. Table 4 indicates the analysis results. 


\section{Table 4}

Analysis Results from the Bootstrap Quantile Regression

\begin{tabular}{|c|c|c|c|c|c|}
\hline Variables & Q 0.20 & Q 0.40 & Q 0.60 & Q 0.80 & Q 0.95 \\
\hline MIG & $\begin{array}{l}0.00438^{* *} \\
(0.00211)\end{array}$ & $\begin{array}{l}0.00683^{* * *} \\
(0.001510)\end{array}$ & $\begin{array}{l}0.00833^{* * *} \\
(0.001603)\end{array}$ & $\begin{array}{c}0.010886^{* * *} \\
(0.001806)\end{array}$ & $\begin{array}{c}0.013977^{* * *} \\
(0.002671)\end{array}$ \\
\hline$E D U$ & $\begin{array}{l}0.12092^{* * *} \\
(0.006679)\end{array}$ & $\begin{array}{l}0.12017^{* * *} \\
(0.005185)\end{array}$ & $\begin{array}{c}0.131197^{* * *} \\
(0.006899)\end{array}$ & $\begin{array}{c}0.136852^{* * *} \\
(0.007804)\end{array}$ & $\begin{array}{c}0.131511^{* * *} \\
(0.005047)\end{array}$ \\
\hline UNEMP & $\begin{array}{l}-0.0077^{* *} \\
(0.00302)\end{array}$ & $\begin{array}{c}-0.008309^{* *} \\
(0.002763)\end{array}$ & $\begin{array}{c}-0.007008^{* *} \\
(0.003338)\end{array}$ & $\begin{array}{c}-0.006066^{* *} \\
(0.002986)\end{array}$ & $\begin{array}{l}-0.006289^{*} \\
(0.003645)\end{array}$ \\
\hline INF & $\begin{array}{l}0.02668^{* * *} \\
(0.006015)\end{array}$ & $\begin{array}{c}0.026734^{* * *} \\
(0.004606)\end{array}$ & $\begin{array}{c}0.0278776^{* * *} \\
(0.005925)\end{array}$ & $\begin{array}{c}0.0318459^{* * *} \\
(0.005830)\end{array}$ & $\begin{array}{c}0.034191^{*} \\
(0.005477)\end{array}$ \\
\hline CONS & $\begin{array}{l}0.24071^{* * *} \\
(0.073109)\end{array}$ & $\begin{array}{l}8.34462^{* * *} \\
(0.054650)\end{array}$ & $\begin{array}{c}8.288007^{* * *} \\
(0.078084)\end{array}$ & $\begin{array}{l}8.29590^{* * *} \\
(0.091294)\end{array}$ & $\begin{array}{l}8.44702^{* * *} \\
(0.056515)\end{array}$ \\
\hline Observations & 312 & & & & \\
\hline
\end{tabular}

${ }^{*} p<0.01,{ }^{* *} p<0.05,{ }^{* * *} p<0.10$. Robust standard errors are given in the parentheses.

In the analysis, $20^{\text {th }}, 40^{\text {th }}, 60^{\text {th }}$, and $80^{\text {th }}$ quantiles were used, as well as the $95^{\text {th }}$ quantile for extreme values. According to the study results, a statistically significant and positive relationship is present between net migration and real GDP per capita for all quantiles. Namely, net internal migration increases growth in all of Turkey's NUTS-2 regions. However, this effect is stronger on higher income levels. As such, internal migration affects growth more in higher income regions. Given that the direction of migration is from low-income regions to high-income regions, migrations are concluded to increase regional disparities in Turkey.

When examining the effects of other variables on GDP per capita, a statistically significant and positive relationship is seen between education and GDP per capita in all quantiles, with this effect being greater at higher income levels. A statistically significant and positive relationship also exists between inflation and GDP per capita in all quantiles. Similarly, the effect of inflation on income is greater in high-income regions. Meanwhile, a statistically significant and negative relationship is found between unemployment and GDP per capita in in all quantiles. 


\section{Conclusion}

Migrations affect both socio-cultural and economic life, affecting a wider geography when occurring internationally and affecting all in-migration and out-migration regions when occurring within a country, Today, countries such as Burundi, Iraq, and Syria, where civil war and chaos are experienced, have had a significant portion of their populations forced into internal migration for the safety of life and property; in countries where chaos is not experienced, migration shows a similar trend due to both the inadequacy of social facilities and limited job opportunities in rural areas. In this context, migration affects all regions in both situations in many ways. In some countries, internal migration reduces regional imbalances through channels such as wages and remittances, which can increase imbalances through production, consumption, and productivity channels in other regions. In the context of regional development, internal migration additionally affects low-income regions more in some countries, while in others it may affect high-income regions more.

This study analyzes the effect of internal migration on regional disparities using the bootstrap quantile regression method in Turkey's NUTS-2 regions for the 2008-2019 period. According to the analysis findings, net internal migration increases growth in all NUTS-2 regions, but this effect is stronger in regions with higher income levels. In this context, as the income levels of a region increases, the effect of net migration on growth increases. Considering that the direction of migration is generally from low-income regions to high-income regions, internal migration has been found to increase interregional disintegration in Turkey. When examining the sectoral structures of the regions in Table 2, the regions where the agricultural sector is strongest are seen too be the low-income regions while regions where the industrial sector is strongest are seen to be high-income regions. As one of the most important sources of growth, the industrial sector being the engine of growth in Turkey (Tuncer \& Özuğurlu, 2004) and the agricultural sector not having much of an effect on poverty (Cuong, 2010) support these findings. In this context and as emphasized by Bayraktar and Özyllmaz (2019), the higher value added from the industrial sector, which is positively affected by migration makes the impact of migration on economic growth in high-income regions stronger when compared to the agricultural sector.

When examining the effects of other variables on GDP per capita, a statistically significant and positive relationship is seen to exist between education and GDP per capita in all quantiles, with this effect being greater at higher income levels. A statistically significant and positive relationship is also present between inflation 
and GDP per capita in all quantiles. Similarly, the effect inflation has on income is greater in high-income regions. However, a statistically significant and negative relationship exists between unemployment and GDP per capita in all quantiles.

In summary, considering that the migration direction is from low-income regions to high-income regions, this suggests that internal migration increases regional disparities. In this context, when migration occurs toward low-income regions, the population increases in these regions, which leads to greater production and consumption. This process, which make rural development possible, reduces regional disparities.

In minimizing the impact migration has on regional disparities, public policies for migration are important. In this context, the following policies are recommended: (Özyılmaz, 2018):

i) Creating pull factors for low-income regions; in this context, qualified workforce should be directed to these regions through regulations that will direct migration.

ii) Migration to low-income regions should be encouraged by improving education, health, and socio-cultural conditions. For example, opening universities in each city has increased migration to these regions, this can thus be said to be a successful policy in this regard.

iii) Public support should be provided as direct public investments or public-private enterprise investments rather than as incentives. Thus, employment opportunities increase in these regions, which leads to an increase in human capital. This ultimately positively affects rural development in low-income regions.

iv) In low-income regions, transforming cities with development potential into attractive places of living ensures firm clustering in these centers with public support; in addition to infrastructure investments, the potential of the region should be increased by involving the public in complementary sectors where the private sector is not found.

v) The construction sector, which has an important share in the national economy, should be supported as a means of migration to low-income regions. In this context, the cost of housing in these regions should be reduced with incentives, and reselling should be prevented by imposing residence requirements.

vi) Considering the weak impact housing has just on immigration, migration to low-income regions should be encouraged through support such as early retirement for return migrants. 
vii) The direction of migrations should be determined by revising agricultural policies to include structural changes that will encourage migration to rural areas. Migration to these regions should be encouraged by creating pull factors such as covering the costs of return migration, agricultural support, and land and housing support. In this context, turning some provinces into agricultural production centers is one of the policies for encouraging migration.

\section{References | Kaynakça}

Ackah, C., \& Denis, M. (2012). Internal migration in Ghana: Determinants and welfare impacts. International Journal of Social Economics, 39(10), 764-784.

Adams, R. H., \& Alfredo, C. (2013). The impact of remittances on investment and poverty in Ghana. World Development, 50, 24-40.

Airola, J. (2007). The use of remittance income in Mexico. International Migration Review, 41(4), 850-859.

Amuedo-Dorantes, C., \& Pozo, S. (2010). Accounting for remittance and migration effects on children's schooling. World Development, 38(12), 1747-1759.

Barro, R. J., \& Sala-i-Martin, X. (2004). Economic Growth ( $2^{\text {nd }}$ ed.). MIT Press.

Bayraktar, Y., \& Özyllmaz, A. (2017). The role of internal migration on regional inequality: Turkey example. Turkish Journal of Middle Eastern Studies, Special Issue, 9-30

Bayraktar, Y., \& Özyılmaz, A. (2018). Regional analysis of internal migration and poverty relationship in Turkey. Journal of European Theoretical and Applied Studies, 6(2), 1-11.

Bayraktar, Y., \& Özyılmaz, A. (2019). Türkiye'de iç göç ve ekonomik büyüme. İş ve Hayat, 5(9), 100-111.

Bayraktar, Y., Özyılmaz, A., Toprak, M., Işık, E., Büyükakın, F., \& Olgun, M. F. (2020). Role of the health system in combating Covid-19: Cross-section analysis and artificial neural network simulation for 124 country cases. Social Work in Public Health, 35, 1-16.

Borozan, D. (2017). Internal migration, regional economic convergence, and growth in Croatia. International Regional Science Review, 40(2), 141-163.

Boyd, M. (1989). Family and personal networks in international migration: Recent developments and new agendas. International Migration Review, 23(3), 638-670.

Broeck, K. V. D., \& Helene, B. L. (2011). Economic drivers of migration and climate change in LDCs. Global Environmental Change, 21(1), 70-81.

Buchinsky, M. (1998). Recent advances in quantile regression models: A practical guideline for empirical research. Journal of human resources, 33(1), 88-126.

Bunea, D. (2011). Cross-country internal migration and convergence in Romania. Annales Universitatis Apulensis Series Oeconomica, 13(2), 508-521.

Čiarnienè, R., \& Kumpikaitè, V. (2008). The impact of globalization on migration processes. Socialiniai Tyrimai, 3(13), 42-48.

Coulombe, S., \& Tremblay, J. F. (2009). Migration and skills disparities across the Canadian provinces. Regional Studies, 43(1), 5-18. 
Cuong, N. V. (2010). Does agriculture help poverty and inequality reduction? Evidence from Vietnam. Agricultural Economics Review, 11(1), 44-56.

Derlacz, J. W. (2009). The impact of internal and international migration on regional convergence in Poland. In W. Migracje (Ed.), Contemporary migrations: European and Polish dilemma. University of Warsaw.

Deshingkar, P., \& Sven, G. (2004). Voluntary internal migration: An update. London: Overseas Development Institute.

Erilli, N., \& Çamurlu, S. (2018). Kantil regresyon analizinde bootstrap tahmini. Erciyes Üniversitesi Fen Bilimleri Enstitüsü Fen Bilimleri Dergisi, 35(2), 16-25.

Erkan, R., \& Erdoğdu, Ö. G. M. Y. (2006). Göç ve çocuk suçluluğu. Sosyal Politika Çalışmaları Dergisi, 9(9), 79-90.

Es, M., \& Ateş, H. (2004). Kent yönetimi, kentlileşme ve göç: Sorunlar ve çözüm önerileri. Sosyal Siyaset Konferansları Dergisi, 48, 205-248

Fawcett, J. T. (1989). Networks, linkages, and migration systems. International Migration Review, 23(3), 671-680.

Fratesi, U., \& Percoco, M. (2014). Selective migration, regional growth and convergence: Evidence from Italy. Regional Studies, 48(10), 1650-1668.

Fratesi, U., \& Riggi, M. R. (2007). Does migration reduce regional disparities? The role of skill-selective flows. Review of Urban and Regional Development Studies, 19(1), 78-102.

Freeman, C. (1997). The economics of industrial innovation. Social Science Electronic Publishing, 7(2), 215-219.

Gezici, F., \& Hewings, G. J. D. (2004). Regional convergence and the economic performance of peripheral areas in Turkey. Review of Urban and Regional Development Studies, 16(2), 113-132.

Gómez, M. G., \& Giráldez, M S.O. (2017). The causality between economic growth and immigration in EU/EFTA member states. Departamento de Economía Aplicada Working Paper, No: 17/01. Retrieved from http:// webx06.webs4.uvigo.es/wp-content/uploads/2019/05/wp1701.pdf

Guest, P. (1998). Assessing the consequences of internal migration: methodological issues and a case study on Thailand based on longitudinal survey data. In R. Bilsborrow (Ed.)., Migration, Urbanization, and Development: New Directions and Issues. Springer Netherlands. UNFPA,

Gurgand, M., Vendryes., T., \& Ximing, Y. (2014). Internal migration and rural development in China: A case study using the 2001 Hukou system reform. Retrieved from https://ferdi.fr/dl/df-hFX4A3bdJm2ZzsZcg8fxRZTH/ document-internal-migration-and-rural-development-in-china-a-case-study.pdf

Güriş, S., \& Şak, N. (2019). Çevresel Kuznets eğrisi hipotezinin toplamsal olmayan sabit etkili panel kantil yöntemiyle incelenmesi. Business and Economics Research Journal, 10(2), 327-340.

Haque, N. U., \& Kim, S.-J. (1995). Human capital flight: Impact of migration on income and growth. IMF Staff Papers, 42(3), 577-607.

Harris, J., \& Todaro, M. P. (1970). Migration, unemployment and development: A two sector analysis. American Economic Review, 60, 126-142.

Hicks, J. R. (1932). The theory of wages. London: Macmillan.

Hoechle, D. (2007). Robust standard errors for panel regressions with cross-sectional dependence. The Stata Journal, 7(3), 281-312.

Kangasniemi, M., Mas, M., Robinson, C., \& Serrano, L. (2012). The economic impact of migration: Productivity analysis for Spain and the UK. Journal of Productivity Analysis, 38(3), 1-37. 


\section{insan \& toplum}

Kırdar, M. G., D., \& Saracoğlu, Ş. (2012). İ̧̧ö̧̧, bölgesel yakınsama sorunu ve ekonomik büyüme: Türkiye örneği. TEK Discussion Paper, No. 2012/75. Retrieved from: https://www.econstor.eu/ bitstream/10419/81605/1/726107506.pdf

Koenker, R. (2005). Kantil regression. New York: Cambridge University Press.

Koenker, R., \& Bassett, J. G. (1978). Regression quantiles. Econometrica: Journal of the Econometric Society, 46(1), 33-50.

Lee, E. S. (1966). A theory of migration. Demography, 3(1), 47-57.

Leping, K. O. (2005). Public-private sector wage differential in Estonia: Evidence from quantile regression. University of Tartu Faculty of Economics and Business Administration Working Paper No: 39. Retrieved from: https://papers.ssrn.com/sol3/papers.cfm?abstract_id=868487

Lewis, W. A. (1954). Economic development with unlimited supplies of labor. The Manchester School of Economic and Social Studies, 22, 139-191.

Lipton, M. (1980). Migration from rural areas of poor countries: The impact on rural productivity and income distribution. World Development, 8(1), 1-24.

Mare, D. C., Fabling, R. M., \& Stillman, S. (2011). Immigration and innovation. London: Motu Economic and Public Policy Research Working Paper, No. 11-05. Retrieved from: https://papers.ssrn.com/sol3/papers. cfm?abstract_id=1851871

Massey, D. S., \& Garcia-Espana, F. (1987). The social process of international migration. Science, 237(14), 733-738.

Maza, A. (2006). Migrations and regional convergence: the case of Spain. Jarbuch fur Regionalwissenschaft, 26(2), 191-202.

Nguyen, L. D., Raabe, K., \& Grote, U. (2013). Rural-urban migration, household vulnerability and welfare in Vietnam. World Development, 71, 79-93.

Organisation for Economic Co-operation \& Development. (2016). The economic impact of migration: Why the local level matters. International Migration Outlook, Retrieved from: http://www.oecd.org/els/mig/ IMO-2016-chap3.pdf.

Østbye, S., \& Westerlund, O. (2007). Is migration important for regional convergence? Comparative evidence for Norwegian and Swedish counties 1980-2000. Regional Studies, 41(7), 901-915.

Özel, H. A., \& Sezgin, F. (2012). Ticari serbestleşme-ekonomik büyüme ilişkisinin bootstrap kantil regresyon yardımıyla analizi. İstanbul Üniversitesi İktisat Fakültesi Mecmuası, 62(2), 283-303.

Öztürk, M., \& Altuntepe, N. (2008). Türkiye'de kentsel alanlara göç edenlerin kent ve çalışma hayatına uyum durumları: Bir alan araştırması. Journal of Yaşar University, 3(11), 1587-1625.

Özyılmaz, A. (2018). İ̧̧ göçlerin bölgesel dengesizlik üzerindeki etkisi: Türkiye örneği (Unpublished doctoral dissertation). İstanbul Üniversitesi Sosyal Bilimler Enstitüsü, İstanbul.

Özyılmaz, A., Bayraktar, Y., \& Toprak, M. (2019). Uluslararası göçmen havalelerinin gelir eşitsizliği üzerine etkisi: Türkiye üzerine ampirik bir analiz. Sakarya İktisat Dergisi, 8(4), 297-310.

Persson, J. (1997). Convergence across the Swedish counties 1911-1993. European Economic Review, 41, 1835-1852.

Phan, D., \& Coxhead, I. (2010). Inter-provincial migration and inequalities during Vietnam's transition. Journal of Development Economics, 91(1), 100-112. 
Piesse, M. (2014). Factors influencing migration and population movements. Strategic Analysis Paper. Retrieved from: https://www.futuredirections.org.au/publication/factors-influencing-migration-and-populationmovements/

Piore, M. J. (1979). Birds of passage: Migrant labor in industrial societies. Population and Development Review, 7(3), 527-529.

Ravenstein, E. G. (1885). The laws of migration. Journal of the Statistical Society of London, 48(2), 167-235.

Ravenstein, E. G. (1889). The laws of migration. Journal of The Royal Statistical Society, 52(2), 241-305.

Rose, C., Phillips, J. J., Arsenault, N., Meyer, R., Giles, T., \& Azulay, A. (2011). Understanding migration: Curriculum resources for the classroom. Retrieved from: https://repositories.lib.utexas.edu/bitstream/ handle/2152/24542/Migration.pdf?sequence=3

Rosenzweig, M. R. (2005). Consequences of migration for developing countries. In UN Conference on International Migration and Development, Population Division. Retrieved from: https://www.un.org/ en/development/desa/population/events/pdf/expert/8/P08_Rosenzweig.pdf

Rubenstein, C. (2011). Why do people migrate? Retrieved from: http://www.phschool.com/atschool/ap_misc/ rubenstein_cultland/pdfs/Ch3_Issue1.pdf 16 Ekim 2017

Saçıldı, İ. S., \& Koşan, N. İ. (2015). Panel kantil modeller. In S. Güriş (Ed.), Stata ile panel veri modelleri. İstanbul: Der Yayınları

Schultz, P. T. (1971). Rural-urban migration in Colombia. The Review of Economics and Statistics, 53(2), 157-163.

Sjaastad, L. A. (1962). The costs and returns of human migration. Journal of Political Economy, 70(5), 80-93.

Skeldon, R. (1997). Rural-to-urban migration and its implications for poverty alleviation. Asia-Pacific Population Journal, 12(1), 1-16.

Stark, O. (1978). Economic-demographic interactions in agricultural development: The case of rural-to-urban migration. FAO.

Stark, O. (1991). The migration of labor. Oxford: Basil Blackwell.

Stouffer, S. A. (1940). Intervening opportunities: A theory relating mobility and distance. American Sociological Review, 6(6), 845-867.

Thet, K. K. (2014). Pull and push factors of migration: A case study in the urban area of Monywa township, Myanmar. News from the World of Statistics, 1(4), 1-14

Todaro, M. P. (1969). A model of labor migration and urban unemployment in less developed countries. American Economic Review, 59, 138-148.

Todaro, M. P. (1980). Internal migration in developing countries: A survey in population and economic change in developing countries. Chicago: University of Chicago Press.

Tuncer, İ., \& Özuğurlu, Y. (2004). Türkiye ekonomisinde büyüme ve sektörel üretkenlik analizleri: Bölgesel karşılaştırmalar 1980-2000. Türkiye Ekonomi Kurumu, Tartışma Metinleri, 24, 1-86.

Vakulenko, E. (2016). Does migration lead to regional convergence in Russia? International Journal of Economic Policy in Emerging Economies, 9(1), 1-25.

Van Hear., N., Bakewell, O., \& Long, K. (2012). Drivers of migration. Migrating out of poverty. Research Programme Consortium, Working Paper No: 1. Retrieved from: https://opendocs.ids.ac.uk/opendocs/bitstream/ handle/20.500.12413/14821/wp1-drivers-of-migration.pdf?sequence=1\&isAllowed=y 


\section{insan \& toplum}

Wallerstein, I. (1974). The modern world system, capitalist agriculture and the origins of the european world economy in the sixteenth century. California: University of California Press.

Wang, X. (2014). Migration, remittances, poverty and inequality in China: A counterfactual analysis. GATE Lyon SaintEtienne Research Center of Universit Lumire Lyon. Retrieved from: https://core.ac.uk/reader/52302680

Weddige-Haaf, K., \& Clemens, K. (2017). Determinants of regional growth and convergence in Germany. Utrecht University School of Economics Tjalling C. Koopmans Research Institute Discussion Paper Series, No. 17-12.

Williams, N., \& Pradhan, M. S. (2009). Political conflict and migration: How has violence and political instability affected migration patterns in Nepal. Population Studies Center Research Report, No. 09-677. Retrieved from: https://digitalrepository.unm.edu/cgi/viewcontent.cgi?article=1027\&context=nsc_research

Wondimagegnhu, B. A. (2012). Economic impact of rural-urban migration on income and poverty of migrant sending rural households: With evidences from Southern Ethiopia (Doctoral dissertation). Bochum: Ruhr University of Bochum.

Wouterse, F. S. (2008). Migration, poverty, and inequality: Evidence from Burkina Faso. IFPRI Discussion Paper, No.00788.

Zhai, F., Hertel, T., \& Wang, Z. (2003). Labor market distortions, rural-urban inequality and the opening of China's economy. GTAP Working Paper, No. 27.

Zhang, X. (2015). The effects of internal migration on regional inequality in China: Evidence from panel data analysis (Unpublished doctoral dissertation). University of Pittsburgh.

Zhao, X., \& Li, X. (2020). The influence of internal migration on regional innovation in China. Economic ResearchEkonomska Istraživanja, (published online), 498-520. https://doi.org/10.1080/1331677X.2020.1792325

Zhu, N., \& Luo, X. (2010). The impact of migration on rural poverty and inequality: A case study in China. Agricultural Economics, 41(2), 191-204. 